\title{
PRACTICAL GUIDELINES IN ACCOUNTING OR HOW COMMERCIAL BOOKS WERE "KEPT" IN THE EARLY XX CENTURY
}

\section{SLAVENA G. StOYANOVA}

ABSTRACT: As a reflection of the economic reality, accounting, through its specific methods, provides an opportunity to obtain information about the condition and movement of specific objects, an integral part of the property of the enterprise. The information received from the accounting, serves as a basis for outlining guidelines for the development of the economically separate reporting unit. This study presents the importance of accounting manuals. It is considered that through them the accounting activity is presented, described, substantiated and explained.

KEYWORDS: accounting, practical accounting guide,

2020 Math. Subject Classification: $91 B 99$

\author{
ЗА ПРАКТИЧЕСКИТЕ РЪКОВОДСТВА ПО \\ СЧЕТОВОДСТВО ИЛИ КАК СЕ ,ДЬРЖАТ “6 \\ ТЬРГОВСКИТЕ КНИГИ В НАЧАЛОТО НА ХХ ВЕК
}

\section{СЛАВЕНА Г. СТОЯНОВА}

\section{Въведение}

Всяка епоха има своето значение в историята. Развитието на науката, включително и познанието относно отчетността, е резултат от изследванията на много учени и приложни специалисти. Като отражение на икономическата действителност счетоводната отчетност, чрез своите специфични способи, дава възможност за получаване на информация за състоянието и движението на конкретни обекти, съставна част от имуществото 
на предприятието. Получаваната от счетоводството информация служи за база, относно очертаване на насоки за развитието на икономически обособената отчетна единица. Посоченото обосновава значимостта относно разбирането на счетовоството и информацията, която то създава за целите на управлението.

Настоящата публикация представя значимостта на ръководствата по счетоводство, ориентирани към тьрговските предприятия и описващи начина на водене на търговските книги. Счита се, че чрез тях се представя, обосновава и разяснява отчетния процес. Акиентира се върху насоките за прилагане на счетоводството, изложени в ръководствата по счетоводство от началото на $X X$ век.

\section{Изложение}

Еволюцията на човешката цивилизация поставя своя отпечатък върху различни дейности, в това число и върху търговията и търговските взаимоотношения. Развитието на обществените отношения рефлектира върху развитието на търговските отношения и счетоводното им отчитане.

Първоначално всеки търговец сам е водил своите сметки. Нямало е как да станеш търговец без първоначален капитал и без определени счетоводни познания [2]. Разширяването на търговската дейност води до необходимост от развитие и усъвършенстване на отчетния процес, на неговото по-обстойно описване и разясняване, а то от своя страна се постига чрез издаване на специализирана литература по счетоводство. Втората половина на XIX век до началото на XX век е времето на практическото усъвършенстване и теоретичното осмисляне в развитието на счетоводството [6].

Първата книга по счетоводство, написана на български език от български автори - братята Стоян и Христо Караминкови, е „Диплография или как се държат търговски книги“. Тя се ползва продължително време в българската стопанска дейност като ръководство по двойно счетоводство преди Освобождението от 
Practical guidelines in accounting ...

османско владичество [7]. Книгата е издадена на 30 януари 1849 г., и се приема като начало на българската икономическа литература в областта на отчетността. Значимостта ѝ за търговците се обосновава със съдържащите се в нея:

- изисквания към онези, които водят и ще водят счетоводство, прилагайки принципа на двойното счетоводно записване, в чиято същност са стопанските операции и двустранното им отразяване по счетоводните сметки;

- регистрите, необходими за цялостно водене на двойно счетоводство в търговското сдружение;

- примери за начина на отразяване на извършваната от търговеца дейност;

- съдържание на текста на писмата (изпратени или получени), свързани с осъществяваната търговска дейност;

- официални писмени документи, с които се определят задълженията и отговорностите по сключени договори, по създаване на сдружение, по преименуване на същото, по използване на полиците, включително и съдържание на полица;

- особености на менителничното право.

В края на XIX и началото на XX век са публикувани материали на български език в областта на счетоводната отчетност. Такива са: „Учебник по счетоводство или държане на тьрговските книги“ от Д. Т. Душанов (1882 г., Пловдив); „Ръководство за изучаване на двойното италианско счетоводство“ от Ю. И. Маджаров (1896 г., Шумен); „Счетоводство или държане на търговските книги“ от Ив. Юрданов (1885 г., Сливен) [7]. Кьм описаните можем да добавим „Практическо ръководство за водене на търговски книги (задължени със закона за тьрговските книги)“ от Н. Чехларов (1921 г., Шумен), „Практическо ръководство по счетоводство“ от А. Ковачев (1921 г., Стара Загора) и други. Ръководствата са дали тласък на отчетността, особено що се касае до нейната практическа насоченост, представяйки приложението на 
венецианският способ*. Така, от обикновена техника за записване, двойното счетоводство стига до значително по-сложна счетоводна форма [4]. Полезността на ръководствата по счетоводство за търговците е била голяма. В тези ръководства се е съдържала информация за съдържанието на „разни търговски писма“: заръчителни, известителни, ассегнации или полици, търговски омологии или изповедания, соглосително писмо, завещание, возношение (просба, молба за помощ).

В някои практически ръководства от началото на $\mathrm{XX}$ век авторите въвеждат и описват непознати, според тях, думи като[8]:

- римеси - полици за събиране;

- акцепти - полици за изплащане;

- девизи - полици, издадени в чуждестранна валута.

В ръководствата е представено описание и на думите: „кредитори“ и „дебитори“. Представя се разяснение на „ценни книжа", и по конкретно за:

- акции - документи за известен капитал, с който участваме в дадено предприятие;

- облигации - документи за известен капитал, даден взаимообразно на държавата, или някоя община;

- разлика между акции и облигации - „при акциите се получава припадающия се процент печалба, или загуба, според случая, когато при облигациите, при какъвто и да е случай, се получава определения процент лихви““[8].

\footnotetext{
"Венецианският способ, веницианската метода или още наричана италианска метода е представена от Лука Пачоли в книгата му „Обща аритметика, геометрия, учение за пропорциите и отношенията“ от 1494 В трактат единадесети на посочения източник, озаглавен „Трактат за сметките и записванията“, авторът прави уточнението, че ще представи венецианския способ, за да помогне на читателя да изучи едно от условията за правене на търговия - умение за водене на търговски книги и получаване на сведения за имуществото и дълговете. Описват се правилата за прилагане на двустранно счетоводство.
} 
Част от ръководствата съдържат информация относно значението на думи, като:,сконто(отбив)“, „,актив“, „пасив“, „баланс“" [8]. Например:

- актив - всички ценности, които един търговец притежава и има да взема;

- пасив - всички ценности, които един търговец има да дава;

- баланс - равносметка.

Срещат се и описание на това, което трябва да се разбира под думи, като: „вещи“, „обещания“, „услуги“, „неща“ [1], а именно:

- вещи - получените и дадени стоки, пари, недвижими имоти и други предмети, които имат някаква стойност и могат да се разменят;

- обещания - дълговете, т.е. дадените устни или писмени задължения за купени стоки и други предмети, или за получени услуги, които се заплащат след неопределено време или на определена дата; разбират се и земанията, т.е. получените устни или писмени задължения за продадени стоки и други предмети, или правенето на услуги на кредит;

- услуги - облагите, които всеки стопанин получава от разни лица и им ги заплаща безвъзвратно като разноски: за наети от него работници и помещения, за застраховки, за лихви и други, както и тия облаги, които стопанина прави на разни лица и те му ги заплащат безвъзвратно като доходи: за дадени негови имоти под наем, за лихви и други, и всички тия услуги, т.е. разноски и доходи, са за сметка на някоя отделна работа, частно за стопанина или общо като печалба или загуба на предприятието мy;

- неща - всички вещи, обещания (кредити) и услуги, които са предмет на размяна във всяка сделка.

Авторите на ръководства описват и онагледяват, чрез представяне в таблична форма, книгите, които са характерни за двойното счетоводство, като обосновават задължителния 
характер на някои от тях чрез приложимата към момента на съставяне на ръководствата нормативна уредба. Счетоводното законодателство, научната литература и счетоводната практика, както посочва А. Свраков, се явяват отражение на установените икономическа действителност и обществена система [3].

Наред с представените образци на книги, авторите представят и кратка характеристика на книгите, която, считаме е достатъчна, за да разбере читателят как се водят търговски книги. При завеждане и водене на търговски книги в разглеждания период се е спазвала следната последователност:

Първо - съставя се „Инвентар“, в който се вписва актива, пасива и чистия капитал. Този актив, пасив и чист капитал се записва и във форма на „Баланс“ в същия инвентар;

Второ - съставя се първата статия в дневника, в която се задължават активните сметки, а се заверяват пасивните сметки и сметка „Капитал“ със сумите, отразени в „Инвентар“. Пренася се посочената статия в главната книга, с което се откриват всички активни и пасивни сметки и сметка „Капитал;

Трето - откриват се личните сметки (партиди) в партидната книга. Откриват се и сметките в другите спомагателни книги, ако се водят такива;

Четвърто - от операциите през деня се съставят съответните статии в дневника и се пренасят в главната книга;

Пето - всеки месец се съставя пробен баланс за контрол на работата, осыществена от този, който е натоварен да води описаните книги.

В практическите ръководства по счетоводство от началото на XX век намира отражение съдържанието и начина на оформяне на регистьр, наречен дневник. Посоченият регистьр е служел за записване (отразяване) в последователен ред на дневните операции, във форма на статии (пера). Под наименованието на регистъра „Дневник“ се е вписвало името на месеца и годината. Дневникът е бил разделен на шест графи. В първата се е вписвало числото на(от) месеца. Тя става излишна, 
ако числото от месеца се впише между статиите. Във втората графа са се вписвали номерата на страниците на сметките от главната книга. Третата графа е най-широка и е служила за вписване на сметките, с които се е оперирало. Четвъртата графа е служила за вписване на номерата на страниците на сметките от спомагателните книги. Петата и шестата графа (Да дава/Да зема) са били необходими за вписване на суми в лева. Следва описание на протекли стопански процеси (стопански операции) със съответен коментар по тях. Считаме, че описанието се е ползвало от авторите на ръководства с цел по-добра илюстрация на вписванията в дневника. Някои от авторите на практически ръководства представят примери, като първо описват протеклия стопански процес, а след това насочват читателя къде да гледа в дневника и по какъв начин стопанската операция е отразена в дневника.

Статиите, вписвани в дневника, са вземани от фактури, тьрговски писма, бележки (специални образци, в които се записват дадени операции) и наръчник. Обикновено и най-често търговците работят с наръчник (тефтерче), в който последователно се вписват операциите, станали през деня, а вечер, или на другия ден се съставят статиите (перата) в дневник. Всички операции, свързани с документи, е могало и да не се вписват в наръчника, а направо от документите да се съставят статиите в дневника. Добре е било тези документи да се описват в друга отделна книга, като фактурна книга, падежна книга за полиците и други.

В практическите ръководство за водене на търговски книги е представено съдържанието и на друг вид книга, която търговците задължително е трябвало да водят - Главна книга. Тя е служила, както отбелязват някои автори „да държим сметка за всякой вид ценност по отделно - отделно за стоките, за касата, за римесите и т.н., както и за прихода и разхода, донесен от тьрговските ни операции““[7]. За осъществяване на отчетността са се откривали сметките „Каса“, „Стоки“, „Римеси“, „Акцепти“ и 
други, а така също сметки като „Домашни разноски“, „Общи разноски“, „Лихви“ и други. Сметките в главната книга са се водили на „фолио“ - две срещуположни страници, лява - „Да дава“, и дясна - „Да зема“. Страната „Да дава“ се нарича още Дебит (дебитна страна), а страната „Да зема“ - Кредит (кредитна страна). Всяка статия съставена в дневника е пренасяна в главната книга.

Друга книга, която е била задължителна за водене от търговците, е Партидна книга (за дебиторите и кредиторите или за лицата, които ни дължат и за лицата, на които ние дължим). В нея са били откривани личните сметки (партиди) на дебиторите и кредиторите. Тя се явявала спомагателна книга на(към) сметка „Дебитори и Кредитори“, открита в главната книга. Веднага след съставяне на инвентара и откриване на сметките в главната книга ca ce откривали личните сметки на дебиторите и кредиторите, които са водени също на фолио (две срещуположни страници). Ако през годината се появят нови дебитор/и и/или кредитор/и, то за всеки се е откривала отделна сметка в партидната книга. Отразяването на протекъл процес (стопанска операция, от която произлиза счетоводна статия), засягащ дебитори и/или кредитори ce е осьществявало, като се е спазвала описаната вече последователност: отразяване в дневника, след това в главната книга - в сметка „Дебитори и кредитори“, след което - в откритата в спомагателната книга лична партида на дебитор или кредитор.

Освен посочените книги търговците са водели и:

$\checkmark$ Касова книга - спомагателна книга на (към) сметка „Каса“ от главна книга, в която се е записвало подробно от какво (от къде) са постьпилите суми и за какво са изразходвани суми;

$\checkmark$ Стокова книга - спомагателна на сметка „Стоки“, водена в главната книга. В стоковата книга намирали отражение сметки за всеки вид стока (аналитични партиди към синтетична сметка „Стоки“). Характерно е, че в посочената книга освен стойностен се е използвал и натурален измерител - брой, литри, метри, вид 
на опаковката. Вписванията в сметките, открити в стокова книга, са се осъществявали въз основа на писма, фактури, дневникът, дневен бюлетин (ако е воден такъв) и други документи;

$\checkmark$ Полична книга - книга за римесите и акцептите - в нея са откривани сметка „Римеси“ и сметка „Акцепти“. В тях са се описвали подробно полиците. Описанието е съдържало място на изплащане, име на издателя, падеж и друга информация. Книгата ce е явявала спомагателна на сметка „Римеси“ и сметка "Акцепти“" от главната книга;

$\checkmark$ Книга за текущите лихвени сметки - спомагателна на сметка „Текущи лихвени сметки“ от главната книга. В нея са се откривали по отделно сметките на банкови институции или лица, в които търговецът е имал открити текущи лихвени сметки. Тук са се изчислявали и лихвите;

$\checkmark$ Книга за ценните книжа - служила е за откриване на сметка „Акции“ и сметка „Облигации“. Книгата се е явявала спомагателна на сметка „Ценни книжа“ от главната книга;

$\checkmark$ Книга за приходите и разходите - служила е да се държи подробна сметка за всички приходи и разходи. Например, относно общите разноски са се откривали отделни сметки за наеми, за канцеларски разходи и други. За лихвите - по отделно сметки за лихви от дебитори и кредитори, за лихви от текущи сметки и други.

В края на всеки месец се е съставял месечен пробен баланс, чиято роля е била осъществяване на контрол върху работата на тези, които са натоварени да водят посочените вече книги. При точно водене на търговските книги винаги трябва да се получат следните равенства:

$\checkmark$ в дневника - сбора на дебита (графа „Да дава“) трябва да бъде равен на сбора на кредита (графа „Да зема“);

$\checkmark$ в главната книга - сбора на салдо дебит на сметките трябва да се равнява на сбора на салдо кредит на сметките от главната книга; 
$\checkmark$ в партидната книга - сбора на дебита на всички лични сметки трябва да се равнява на сбора на дебита на сметка „Дебитори и Кредитори“ от главната книга, а сбора на кредита на всички лични сметки от партидната книга трябва да се равнява на сбора на кредита на сметка „Дебитори и Кредитори“ от главната книга.

Подобни разсъждения са се извършвали, и наличие на равенства се е проверявало, и в останалите книги които са се водили от търговеца или от друго, посочено от него лице. По този начин е била извършвана проверка и е бил осъществяван контрол върху счетоводната работа.

Ръководствата по отчетност са съдържали информация и за начина на представяне на видовете сметки, които тьрговците са били задължени да откриват и по които са извършвали вписвания. Сметките са разделени на активни, пасивни и приходо-разходни. При активните сметки, които са служели за представяне на началното състояние и промените, които са настъпвали в обектите (каса, стоки, ценни книжа, движими имоти и други), салдото или остатькът е винаги в страната на дебита. При пасивните сметки, които са служили за отчитане на пасиви (акцепти, кредитори, капитал и други), салдото е винаги салдокредит. Понеже сметка „Дебитори“ (активна) и сметка „Кредитори“ (пасивна) през изследвания период са съединени в една обща сметка „Дебитори и кредитори“, то салдото на тази сметка е можело да бъде посочвано в дебитната страна на сметката или в нейната кредитна страна, в зависимост от това дали сумата на дълга на дебиторите е по-голям от сумата на дълга към кредиторите или обратно. Салдото на сметките, влизащи в състава на групата на приходо-разходните сметки е можело да бъде в дебитната или кредитна страна на съответната сметка. Ако е реализирана печалба (приход) по дадена сметка, салдото иे бива кредитно. Ако е реализирана (има) загуба (разход), салдото на съответната сметка бива дебитно. 
В края на всяка година се е извършвало приключване на сметките от главната и спомагателните книги, като такова приключване е можело да стане и по друго време в годината при нужда. В ръководствата е описвана подробно и техниката на годишно приключване.

\section{Заключение}

Втората половина на XIX век до началото на XX век е период, свързан с практическо усъвършенстване и теоретично осмисляне в развитието на счетоводството. Съществуващите ръководства по счетоводство са били добра основа за водене на отчетност на търговеца, съобразена с действащата към момента на издаване нормативна уредба. Чрез ръководствата се разширява информацията относно това кой точно е задължен да води счетоводни книги, кои счетоводни книги са били задължителни, как е следвало да се водят тези книги. Много от сметките и регистрите, описани в настоящата публикация са приложими и днес. Технологията на отчетността в областта на търговията, макар и усъвършенствана към днешна дата, е запазила основните принципи, правила и процедури, характерни за счетоводството.

\section{ЛИТЕРАТУРА:}

[1] Ковачев, А.. Практическо ръководство по счетоводство, Ст Загора, 1921

[2] Свраков, А. Година на три юбилейни дати и годишнини за професията на независимите финансови одитори в България, Счетоводство, данъци и право, бр.2, 2021, с.5-20

[3] Свраков, А. Размисли за счетоводството в минало и настояще време, ИК „Труд и право“, С., 2014г.

[4] Свраков, А., Монева, И., Грозева, Н. Учебно ръководство по основи на счетоводството, Университетско издателство ВСУ „Черноризец Храбър“, Варна, 2013

[5] Спасов, Д. Счетоводството по българските земи, издание на Стопанска академия „Д. А. Ценов“, Свищов, 2000 
Stoyanova S.

[6] Стоянов, С., Савова, К., Николова, Н. Обща теория на счетоводството, Издателски комплекс УНСС, С., 2021

[7] Стоянов, С., Савова К. Теории, системи и школи в счетоводството Издателски комплекс УНСС, С., 2015.

[8] Чехларов, Н., Практическо ръководство за водене на търговски книги (задължени със закона за търговските книги), Шумен, 1921

\section{Славена Стоянова}

ШУ „Епископ Константин Преславски“, Факултет по математика и информатика, катедра „Икономика и математическо моделиране“ e-mail: slavena.stoyanova@shu.bg 